\title{
Insurance and reinsurance in the Fairchild enclave
}

Article

Accepted Version

Merkin, R. (2016) Insurance and reinsurance in the Fairchild enclave. Legal Studies: The Journal of the Society of Legal Scholars, 36 (2). pp. 302-325. ISSN 1748-121X doi:

https://doi.org/10.1111/lest.12109 Available at https://centaur.reading.ac.uk/90250/

It is advisable to refer to the publisher's version if you intend to cite from the work. See Guidance on citing.

To link to this article DOI: http://dx.doi.org/10.1111/lest.12109

Publisher: Cambridge University Press

All outputs in CentAUR are protected by Intellectual Property Rights law, including copyright law. Copyright and IPR is retained by the creators or other copyright holders. Terms and conditions for use of this material are defined in the End User Agreement.

\section{www.reading.ac.uk/centaur}

\section{CentAUR}

Central Archive at the University of Reading

Reading's research outputs online 


\title{
INSURANCE AND REINSURANCE IN THE FAIRCHILD ENCLAVE
}

\author{
Rob Merkin*
}

\section{INTRODUCTION}

\section{How did we get here? ${ }^{1}$}

The dreadful disease of mesothelioma, caused by exposure to asbestos, has a number of features that pose almost intractable problems for tort law and liability insurance, notably the time-lag of up to 50 years between exposure and injury and the accepted current impossibility of science proving exactly which exposure has given rise to the disease. The Supreme Court has addressed tort and insurance issues on no fewer than six occasions, ${ }^{2}$ most recently in Zurich Insurance PLC UK Branch v International Energy Group Ltd ${ }^{3}$ (IEG), a case in which a specially convened sevenjudge panel split $4: 3^{4}$ on the correct analysis of the insurance position. This article analyses the reasoning and its implications, and it also highlights the author's contention that the study of tort law in a conceptual vacuum free of insurance omits the important issue of when and by whom compensation will actually be paid ${ }^{5}$ and paints at best a partial picture of the development of tort principles. ${ }^{6}$ As will be seen, IEG is unlikely to be the end of the story. Most of the cases have involved exposure of employees to asbestos, and discussion is directed primarily to that context. A brief outline of the authorities will suffice to set the background to IEG.

\section{Liability for mesothelioma}

An employee may have been exposed to asbestos over an extended period by his employer, and if there is no other source of exposure then a tort claim against the employer - assuming that negligence is present - is relatively straightforward. However, if there has been exposure by two or more employers, or if there are periods of selfemployment where exposure took place, an immediate causation issue arises. That was addressed by the House of Lords in Fairchild $v$ Glenhaven Funeral Services Ltd, ${ }^{7}$ where existing causation principles were set aside and liability was imposed upon each exposing employer despite the inability of the victim to demonstrate a causal link between exposure and injury. Fairchild inevitably received a mixed reception, with views ranging from outrage at illicit tampering with established tort rules to cautious welcome for a pragmatic solution to a situation that the law in its then state could not accommodate. ${ }^{8}$ It was inevitable that Fairchild would raise insurance issues, ${ }^{9}$ in that the new form of liability would have to be paid for at some point, but they were not articulated by the courts at the time, perhaps in the hope that the market would reach voluntary resolution.

Fairchild was widely believed to have the consequence that every employer was liable for $100 \%$ of the loss irrespective of the duration and intensity of exposure, but that possibility was rapidly undermined by the House of

\footnotetext{
* QC, Professor of Law, University of Exeter. The author is grateful to Michelle George of Chadbourne \& Parke LLP, and also to two anonymous referees, for valuable comments on an earlier draft of this article.

${ }^{1}$ Merkin and Steele, Insurance and the Law of Obligations OUP, 2013, chapter 12.

${ }^{2}$ Seven, if the abortive attempt by the Welsh Assembly to impose retroactive tort and insurance liability for the costs of treating mesothelioma is counted: Re Recovery of Medical Costs for Asbestos Diseases (Wales) Bill [2015] UKSC 3

${ }^{3}$ [2015] UKSC 33.

${ }^{4}$ Lords Mance, Clarke, Carnwath and Hodge; Lords Neuberger, Reed and Sumption dissenting. The majority judgment was delivered by Lord Mance, with a short supplementary judgment by Lord Hodge; the dissenting judgment was written by Lord Sumption, with Lords Neuberger and Reed adding some concluding comments.

${ }^{5}$ In that tort is the "gatekeeper" of access to insurance funds: see Merkin and Steele, op cit, n 1, at p 278.

${ }^{6}$ The traditional view to the contrary of Jane Stapleton. "Tort, Insurance and Ideology" (1995) 58 MLR 820, has not it is submitted - withstood scrutiny: Abraham, The Liability Century 2008, Harvard University Press; Baker, "Liability Insurance as Tort Regulation" (2005) 12 Conn Ins LJ 1; Morgan, “Tort, Insurance and Incoherence” (2004) 67 MLR 384; Merkin, “Tort, Insurance and Ideology: Further Thoughts” (2012) 75 MLR 301

7 [2002] UKHL 22; [2003] 1 AC 32.

${ }^{8}$ The literature is voluminous. See: Clerk and Lindsell on Torts, $21^{\text {st }}$ ed 2014, Sweet \& Maxwell, ch 2; Morgan, "Lost Causes in the House of Lords" 66 MLR 277 (2003); Miller, "Judicial Approaches to Contested Causation" (2002) 1 Law, Probability and Risk 119; Porat and Stein, "Indeterminate Causation and Apportionment of Damages" (2003) 23 OJLS 667; Amirthalingam, "Causation, Risk and Damage” 126 LQR 162 (2010); Bailey, "Causation in Negligence: What is Material Contribution? (2010) 30 LS 167.

${ }^{9}$ Merkin, "Fairchild and Insurance" 120 LQR 233 (2004).
} 
Lords' ruling in Barker $v$ Corus UK Ltd.${ }^{10}$ The effect of Barker was that liability was proportionate, so that every employer was responsible only for its own contribution to the increased risk of the disease. Thus, assuming a consistent intensity of exposure, each employer faced liability only for its own proportion of the overall period of exposure, so that if there were non-tortious periods of exposure there would be no liability in respect of them. The outcome was that the victim would have to sue each insurer for its own proportion, and to bear any part of the loss attributable to nontortious exposure. It remained unclear after these cases whether the basis for liability was the replacement of the "but for" causation test with a "weak" version of causation that was satisfied where injury followed exposure, or whether their Lordships had created a new tort of increasing the risk of injury. That matter was resolved in favour of "weak" causation by a majority of the Supreme Court in Durham v BAI (Run off) Ltd, Employers' Liability Trigger Litigation ${ }^{l I}$ (Trigger).

The Barker case left the victim of exposure in a difficult position, being potentially faced with the need to bring as many actions as there were employers and also with an absence of compensation representing periods of non-tortious exposure. ${ }^{12}$ Parliament responded rapidly to Barker by adopting s 3 of the Compensation Act 2006. The section sets out a series of cumulative requirements which, if satisfied, allow the victim to seek recovery for the entirety of his injuries from any one responsible person guilty of exposure. ${ }^{13}$ Those requirements are: tortious exposure; the contracting of mesothelioma; the inability of medical science to determine whether exposure was the cause of the injury; and liability in tort. The pinning of $100 \%$ liability on any one responsible person, of the victim's choice, is ameliorated by rendering liability joint and several, so that a responsible person can seek contribution on a proportional basis (which will generally be duration of exposure unless there is a variation in intensity of exposure) from any other responsible person. Damages cannot be reduced by any period of non-tortious exposure, although the section does preserve the right of a responsible person to plead contributory negligence. The view prevailing after Fairchild was, by that means, restored. ${ }^{14}$

\section{Insurance coverage}

Insurance against injury at work has been compulsory since the implementation in 1972 of the Employers' Liability (Compulsory Insurance) Act 1969. ${ }^{15}$ In practice, many claims brought against employers are worthless unless the liability is backed by insurance, because in the time between exposure and injury the employer either has ceased to exist or has become insolvent. In those circumstances the victim has a claim against the insurers under the Third Parties (Rights against Insurers) Act 1930, to be replaced in $2015^{16}$ by a more logical scheme under the Third Parties (Rights against Insurers) Act 2010 whereby it is unnecessary for the victim to revive a struck off employer so that its liability can be established for the purposes of a claim against the insurers.

Although Fairchild as supplemented by the Compensation Act 2006 resolved the question of tort liability, nothing was said about insurance. Policies in 1960's and onwards varied in their wording, but some (around 15 per cent) responded to claims against the employer for "injury sustained" or "disease contracted" by an employee in the year of coverage. If those words of coverage referred to the date on which lung damage occurred, typically up to 50 years after exposure, then few of these policies would have been called upon to respond. That was because the victim was most unlikely to have remained an "employee" at the date of the injury. Accordingly, unless the insuring terms referred to the date of exposure, there could be a black hole in insurance coverage. A test case, in the guise of a public liability policy, was taken to the Court of Appeal in Bolton Metropolitan Borough Council v Municipal Mutual Insurance \&

\footnotetext{
${ }^{10}$ [2006] UKHL 20. See Laleng, "Causal Responsibility for Uncertainty and Risk in Toxic Torts" (2010) 18 Tort LR 102.

${ }^{11}$ [2012] UKSC 14; [2012] 1 WLR 867. See: Steel, "The Trigger Litigation" (2014) 4 PN 285; Merkin and Steele, "Compensating Mesothelioma Victims", 127 LQR 329 (2011); Merkin and Steele, "Historic Asbestos Exposure and Liability Insurance" in Mass Justice, eds van Boom and Steele, 2011, 208.

${ }^{12}$ Ambient exposure to asbestos can, however, be all but discounted following Sienkiewicz v Greif (UK) Ltd [2011] UKSC 10, [2011] 2 AC 229.

${ }^{13}$ Although the Financial Services Compensation Scheme by the Compensation Act 2006 (Contribution for Mesothelioma Claims) Regulations 2006 (SI 2006/3259, authorised the extension of the Financial Services Compensation Scheme, as set out in the Compensation COMP section of the Financial Conduct Authority Handbook, so that a victim may recover under the Scheme where the employer's insurers are insolvent.

${ }^{14}$ It may also be added that there is a statutory compensation scheme in the Mesothelioma Act 2015 for victims first diagnosed with the disease on or after 25 July 2012, but benefits are conditional on no claim for damages having been brought.

${ }^{15}$ There are exemptions to this rule including government department and agencies, local authorities, nationalised industries, police authorities and health service bodies.

${ }^{16}$ Following amendments under the authority of the Insurance Act 2015, correcting technical errors in the 2010 Act which prevented its implementation
} 
Commercial Union Assurance $e^{17}$, the relevant insuring wording there being "accidental bodily injury". The Court of Appeal ruled that "bodily injury" did not arise on exposure but only when the disease took hold, ${ }^{18}$ so that a public liability insurance policy in those terms responded to bodily injury in the year of cover and not to the year of exposure. Public liability insurers objected strongly to this ruling, ${ }^{19}$ pointing out that if an insurer wished to provide cover for historical acts of negligence it would have done so by means of a "claims made" insurance whereby liability attaches in the year in which either a claim is made against the assured to the assured or, by way of alternative under the "deeming clause", the assured becomes aware of circumstances that might give rise to a claim and notifies those circumstances to the insurer in the policy year. ${ }^{20}$

Armed with Bolton, the relevant insurers were confident that a test case on equivalent employers' liability wording would produce the same result. However, in that test case, Trigger, the Supreme Court confined Bolton to public liability and held that "injury sustained" and "disease contracted" in the context of employers' liability insurance referred to the date of exposure, thereby pinning liability upon any insurer on risk at the time of any exposure. ${ }^{21}$ This was a naked policy decision, designed to give effect to Fairchild by matching insurance coverage to tort liability, thereby bringing insurance within what was referred to in IEG as the "Fairchild enclave". As noted above, in Trigger the Supreme Court, by a 4:1 majority, classified Fairchild liability as resting on "weak" causation rather than a new tort of creating the risk of causing disease, thereby removing the argument (accepted by Lord Phillips, dissenting) that it still remained necessary for the insured employer to show that the exposure had caused the injury. It may fairly be said therefore that the circular chain of events set in motion by Fairchild consisted of the matching of insurance coverage to Fairchild liability by Trigger, and then a redefinition in Trigger of the nature of Fairchild liability in order to ensure that insurance claims were not defeated by "but for" causation principles. ${ }^{22}$

\section{The issues in IEG}

In Fairchild the House of Lords established the principle of liability for exposure to asbestos but did not discuss its quantum where there was more than one employer: that was left to Barker and then the Compensation Act 2006. History repeated itself in Trigger, a decision which settled the principle of insurer liability but said nothing about quantum where there was more than one insurer. The market had indeed proceeded on the basis that the relevant test was "time on risk", and settled claims accordingly, ${ }^{23}$ and continued to do so after Trigger. The correct analysis was finally determined by the Supreme Court in $I E G$, a case unusual in two respects: the claims arose in Guernsey, a jurisdiction to which the Compensation Act 2006 does not apply; and the exposing employer remained solvent. The Supreme Court was, by way of consolation, not faced with the complication of multiple employers, one which readers of this article will not be spared.

Mr Carré was employed by GGLCL, IEG's predecessor in title, from 13 November 1961 to 31 December 1988. He was continuously exposed to asbestos on what was assumed to be a consistent intensity. He contracted mesothelioma and in 2008 commenced proceedings against IEG. The claim was rapidly settled, in the sum of $£ 250,000$ plus $£ 15,300$ costs. IEG's own defence costs were $£ 13,151.60$. IEG was insured under an employers' liability policy issued by Excess Insurance from December 1978 to December 1980. Midland Insurance, subsequently taken over by Zurich, provided insurance cover from December 1982 to December 1988. For the rest of the period of exposure, IEG had no insurance coverage. Midland's proportion on risk of the period of exposure was $22.08 \%$. IEG sought to recover its entire loss from Zurich. Given that IEG alone had exposed Mr Carré to asbestos, there was no dispute as to IEG's $100 \%$ liability. IEG claimed that the Fairchild principle had to be traced through to insurance coverage. Thus, applying the "weak" causation test, exposure followed by disease was enough to give rise to liability and it was not incumbent upon IEG to identify which exposure had that effect: indeed, they all did. Accordingly, any insurer on risk at the time

\footnotetext{
17 [2006] EWCA Civ 50; [2006] 1 WLR 1492.

${ }^{18}$ Cf Rothwell v Chemical and Insulating Co Ltd [2007] UKHL 39; [2008] AC 281.

${ }^{19}$ Nothing appears to be written on the point, but the present author can testify to the strength of feeling expressed by an audience of London market liability insurers at a seminar shortly after the Bolton ruling: the author escaped only by pleading the "don't shoot the messenger" defence.

${ }^{20}$ Claims made policies were originally developed for the professional indemnity market and after a brief flirtation with other forms of liability insurance in the 1980s and 1990s have now been restored to their original function. A claims made policy will generally contain a "retroactive date" (typically the date on which the insurer first came on risk) which cuts out liability for acts of negligence committed before that date. Bolton deprived the insurers of the possibility of that protection.

${ }^{21}$ Leaving the somewhat unsatisfactory outcome that the same words bear different meanings in different classes of insurance. Lord Mance, in argument in Trigger, made it clear - with apparent relief - that the correctness or otherwise of Bolton was not at stake and was to be left to another day.

${ }^{22}$ The issues are discussed in more detail in Merkin and Steele, Insurance and the Law of Obligations, OUP, 2013, chapter 12 and Meggitt, “The 'Rock of Uncertainty' - Mesothelioma, Insurers and the Courts” [2013] JBL 563.

${ }^{23}$ Guidelines issues by the Industrial Disease Claims Working Party in 2006, revised in 2008.
} 
of any exposure faced $100 \%$ liability to the assured. That analysis was adopted by the Court of Appeal in IEG. ${ }^{24}$ Zurich's response was that Trigger did not require any such conclusion, and that allocation by time on risk - as per Barker - was appropriate.

As an initial point the Supreme Court unanimously confirmed that Barker had survived Trigger and remained good law in Guernsey. However, in the event, nothing turned on that ruling, because the question of allocation between employers did not arise, IEG having been the sole employer throughout the period of exposure. Had there been two or more employers, then - applying Barker - each of the employers would only have been liable for time on risk and their respective insurers would have had matching liability. In England, under the Compensation Act 2006, each of the employers would have faced $100 \%$ liability, but subject to a right of contribution from other employers (on a time on risk basis) under the Civil Liability (Contribution) Act 1978. What mattered in IEG was whether the reasoning in Barker could be traced through to the insurance of the liability incurred by any one employer. The majority of the Supreme Court held that it could not. The reasoning in Trigger in respect of insurance coverage meant that every exposure giving rise to mesothelioma was an insured event, and that it attracted $100 \%$ of the liability to the victim. The minority view was that an insurer could not be required to pay for liability which arose outside the period of insurance, and accordingly that an insurer was liable only for that proportion of the total liability represented by time on risk.

The majority agreed with the minority sentiment that Trigger produced a result unfair and disproportionate to an insurer on risk for only a relatively short part of the overall period of exposure. Leaving Midland in that position was, in the words of Lord Hodge, "not an option". ${ }^{25}$ However, the majority saw the solution not in laying down a time on risk principle, but in allowing an insurer in that position to exercise restitutionary rights against any other person who had assumed responsibility for any part of the period of exposure. There are thus three important strands in the reasoning of the majority in the Supreme Court. The first is that an insurer on risk for any part of the period of exposure bears $100 \%$ of the liability faced by the assured to a victim. The second is that if there is any other insurer on risk for any part of the period of exposure, the paying insurer has a right of contribution against that other insurer. The third is that if there is a part of the period of exposure where there is no insurance at all, then the paying insurer has a right of recoupment against the assured itself. In that way the loss is allocated as between the insurer and the assured, and replicates the minority position that the starting point is that there is only insurance in place for the proportion of the insured period where cover existed. The majority view casts the primary risk on the paying insurer, the minority leaves the employer (or victim where the employer is insolvent) to recover from other insurers.

Each of the three strands is given more detailed consideration in the following section. The double insurance and recoupment issues did not arise on the reasoning of the minority, but there is nevertheless important discussion of them by Lord Sumption. Thereafter an attempt is made to assess the operation of IEG and in particular to consider the questions that remain outstanding.

\section{2. $100 \%$ LIABILITY}

The notion that an insurer on risk for any part of the period of exposure can face $100 \%$ liability effectively allows the assured to choose where the insurance risk is to fall. All liability can, under the weak causation test, be focused on any insurer and in any year of cover. This is generally referred to as "spiking". The majority in IEG felt driven to its conclusion by the logic of Fairchild and Trigger, although strictly speaking Fairchild is not concerned with insurance and Trigger merely established that the wordings of policies in force at the relevant time imposed liability upon an insurer on risk at a time when exposure took place. Lord Mance nevertheless felt that the outcome was inevitable from Fairchild: ${ }^{26}$

But, having, for wholly understandable reasons, gone down the Fairchild route, the common law must, in my view, face up to the consequences, if necessary by further innovation. That is so, even if some of the problems arise from Parliament's intervention by the 2006 Act ... Parliament's intervention does not release the courts from their role of working out the common law implications of a special rule which remains essentially common law based, although subject to the modification introduced by the 2006 Act ...

Once one accepts that causation equates with exposure, in tort and tort liability insurance law, there is no going back on this conclusion simply because there was exposure by the insured of the victim both within and outside the relevant insurance period.

The minority view was that pinning $100 \%$ liability on any insurer at the option of the assured was far from an inevitable consequence of the earlier authorities, even though denial of the possibility would restrict the practical benefits of Fairchild to a victim whose employer had insurance coverage from solvent insurers for the full period of

\footnotetext{
24 [2013] EWCA Civ 39.

25 [2015] UKSC 33, para 108.

26 At paras 39 and 46.
} 
exposure. The basis of the minority view was that it was conceptually impossible to regard mesothelioma as being caused by each and every exposure, and that it could be caused only once as a result of the cumulative effect of continued exposure. The tort in question was not causing mesothelioma but rather effecting an exposure that created the chance of causing the disease. That meant that an employer was liable for his contribution to that chance, and an insurer was similarly liable only for that contribution. The remedy where there was no insurance in any period of exposure was, in the view of the minority, to be found in the various state compensation schemes. The majority disagreed, pointing out that the Mesothelioma Act 2014 was designed to provide compensation to a victim who had not or could not bring an action against the employer, and thus it could not apply to fill in any gaps in insurance coverage where an action was brought.

The majority recognised the exceptional nature of its approach, noting the general rule that allowing an assured to choose where to place its losses is inconsistent with the principle of uncertainty that underpins insurance law. Just how far off the established path the majority were prepared to stray in IEG can be demonstrated by three earlier decisions, discussed selectively in the majority and minority judgments in IEG. These decisions show that, outside the Fairchild enclave, an insurer cannot face liability for risks occurring outside the temporal limits of the policy, and that an assured cannot "spike" claims in an unnatural order so that insurance recoveries can be maximised. They have wider relevance to possible future developments.

Municipal Mutual Insurance Ltd v Sea Insurance Co $\mathrm{Lt}^{27}$ saw an attempt by a reinsured to spike losses in a single policy year when the probability was that some of them had occurred at other times. There were three contracts of reinsurance for successive years from June 1986 to June 1989. A series of losses occurred between March 1987 and September 1988, representing the last three months of the 1986 policy, the entirety of the 1987 policy and the first three months of the 1988 policy. Waller J held that the insurers, who had paid the claim on the basis that all losses fell within the year June 1987 to June 1988, were entitled to recover fully from the reinsurers on risk under the 1987 policy. The Court of Appeal rejected that conclusion, and held that each policy covered only the loss or damage occurring during the period of cover. Hobhouse LJ commented that "When the relevant cover is placed on a time basis, the stated period of time is fundamental and must be given effect to ... Contracts of insurance (including reinsurance) are or can be sophisticated instruments containing a wide variety of provisions, but the definition of the period of cover is basic and clear." 28 The Court of Appeal was satisfied on the evidence that no more than two-thirds of the loss had occurred in that year, that sum being recoverable, but that there was insufficient evidence as to the amount of loss occurring before and after that year so that the first and third policies did not respond. Lord Mance cited MMI with approval, but held it to be distinguishable in the Fairchild enclave. It nevertheless shows that an assured cannot allocate losses as it thinks fit, particularly where those losses in part occurred outside the policy period.

The importance of temporal limits was put beyond doubt by the House of Lords in Wasa International Insurance Co Ltd $v$ Lexington Insurance $C o,{ }^{29}$ a ruling relied upon heavily by Lord Sumption but not referred to by Lord Mance. ${ }^{30}$ In this case Lexington had, for the period 1 July 1977 to 1 July 1980, insured Alcoa against property damage and business interruption at its numerous sites both within and outside the US. The dispute resolution provisions required Lexington to submit to any court of competent jurisdiction within the United States at the request of Alcoa. Facultative ${ }^{31}$

reinsurance was obtained from London Market reinsurers, including Wasa, for a period of 36 months from 1 July 1977, with the terms of the reinsurance being "as original". The two contracts were thus identically worded, of the same duration and the premium paid for the reinsurance was that paid for the insurance minus a ceding commission retained by Wasa. Alcoa was found to have suffered property damage at its sites before, during and after the insured period, and proceedings were brought against Lexington in Washington. The Washington courts, applying their choice of law rules, held that the applicable law was that of Pennsylvania, and in accordance with that law - derived, ironically, on claims for personal injury from asbestos exposure ${ }^{32}-$ if any property damage occurred within the insured period then the entirety of that damage could be attributed to the insurers. The outcome was that Lexington was found to be liable for something close to 50 years of property damage despite having only insured for a three-year period, a liability which Lexington then sought to pass to its reinsurers under the facultative agreement in reliance on the presumption of back-to-back cover as between insurance and identically worded reinsurance. There was a powerful case based on previous House of Lords authority ${ }^{33}$ for construing the English reinsurance in the same way as the underlying insurance, but the House of Lords refused to do so. What mattered was not that the law in Pennsylvania had changed

\footnotetext{
${ }^{27}$ \{1998] EWCA Civ 946; [1998] Lloyd's Rep IR 421.

28 [1998] Lloyd's Rep IR 421, 436.

29 [2009] UKHL 40; [2010] 1 AC180.

${ }^{30}$ Deliciously ironic, because Jonathan Sumption QC as he then, was appeared for the reinsured in Wasa, but failed to convince a panel, which included Lord Mance, that cover could exceed temporal limits.

${ }^{31} \mathrm{Ie}$, a one-off reinsurance of this single policy.

32 The authorities are discussed in the judgment of Lord Sumption in IEG.

${ }^{33}$ Forsakrings Vesta v Butcher [1989] UKHL 5; [1989] AC 852, where the House of Lords was prepared to apply
} Norwegian rules of construction to an English law facultative reinsurance in order to match the cover provided by the identically worded Norwegian direct policy. 
after the insurance and reinsurance had been entered into, ${ }^{34}$ but rather that it had not been clear from the outset what law would be applied to any dispute between Alcoa and Lexington and accordingly it could not be said that Wasa had agreed to be bound by an unpredictable outcome. If there was ever a case justifying a finding that reinsurers were liable beyond the temporal limits of their policy, this was it. ${ }^{35}$ The point for present purposes is that their Lordships emphasised the significance of temporal limits, and indeed it is possible to read the judgments as indicating that the ousting of the back to back principle on the basis of unpredictable outcome extended only to the most fundamental terms of the reinsurance, in particular the duration of coverage.

The third of the trilogy of cases is Teal Assurance Company Ltd $v$ WR Berkley Insurance (Europe) Ltd, ${ }^{36}$ an allocation decision and one referred to briefly by Lord Mance. The case concerned the application of two settled principles: where claims are made under a policy, and their total exceeds the sum insured, then the claims are to be paid in strict chronological order; and in the case of liability insurance, chronology is determined by the date on which the liability of the assured to the third party is established and quantified by judgment, award or settlement. The outcome is, therefore, "first past the post". ${ }^{37}$ In Teal the assured, BV, had liability insurance in five layers. The first four layers covered worldwide liabilities whereas the top layer excluded US liabilities. Four claims were made against the assured, two from the US and two from outside the US. Unsurprisingly, BV sought to recover the US claims first, because postponing them to the other claims would lead to them being treated as falling within the top layer and thus excluded. ${ }^{38}$ Although the case turned upon the construction of the policies, the Supreme Court confirmed that claims were to be allocated to the insurance in the order that they were established and quantified, and that it was not open to the assured to adjust the order so as to maximise coverage. ${ }^{39}$

The language used in Sea Insurance, Wasa and Teal to deny the possibilities of liability outside temporal limits and of adjusting the timing of liabilities so as to maximise insurance or reinsurance recoveries, is for the most part emphatic. Within the Fairchild enclave, it is apparent that those principles have simply gone by the board. But, if Fairchild is to be effective, then its principle has to be carried through to the very insurance upon which the potential for recovery under Fairchild depends. It is submitted that the majority view, although not strictly reconcilable with established principle, is - as the majority thought - all but inevitable. Once the highest court had jumped through hoops to match liability and insurance coverage, it was unlikely that it would adopt a proportional recovery principle that would threaten actual recovery for periods where there was no insurer or no solvent insurer.

\section{CONTRIBUTION}

\section{The nature of contribution ${ }^{40}$}

The majority, having conferred $100 \%$ liability upon Midland, sought to mitigate that decision by allowing Midland to seek contribution from Excess Insurance in respect of the two years of the latter's coverage of IEG. The minority approach is more complex. It is necessary first to outline the sources of contribution.

Contribution has three guises. First, and in its origins, it is an equitable concept derived from the maxim that "equality is equity" and in its earliest form was designed to prevent one surety bearing the entire burden of a debt. That concept has developed into a general principle. Secondly, contribution applies as between insurers who have insured the same risk, and has a statutory basis under ss 32 and 80 of the Marine Insurance Act 1906. The former section defines "double insurance", allowing the assured to recover the full amount of loss from any one insurer; and the latter section imposes upon each insurer an obligation "to contribute rateably to the loss in proportion to the amount for

\footnotetext{
${ }^{34}$ Insurers have to take the risk of the law changing, so that they have to bear additional liabilities. That established principle was indeed one of the key elements relied on by Lord Mance in Trigger in support of the outcome.

${ }^{35} \mathrm{Mecz}$, "Wasa International Insurance Co Ltd v Lexington Insurance Co: Buyer Beware"; Schaff, "Wasa International Insurance Co Ltd v Lexington Insurance Co: The Limits to the "Back to Back" Presumption" [2010] JBL 9; Gurses: "Reinsurance Contracts: Is Wasa v Lexington the Exception or the Rule?" 73 MLR 119 (2010); Merkin, "Commercial Certainty in the Reinsurance Market" 126 LQR 24 (2010).

${ }^{36}$ [2013] UKSC 57.

${ }^{37}$ Cox v Bankside Members Agency Ltd [1995] 2 Lloyd's Rep 437.

${ }^{38}$ The actual dispute arose at the reinsurance level. BV was insured by its captive, which had matching outwards reinsurance. Liability under the insurance nevertheless determined liability under the reinsurance, and so the arguments related to the insurance coverage.

${ }^{39}$ In a sequel decision, Teal Assurance Co Ltd v W R Berkley Insurance Europe Ltd (No 2) [2015] EWHC 1000

(Comm), Eder J held that the assured's payment of an agreed sum into an escrow account, from which drawings could be made to fund repairs to defective products supplied by the assured, did not establish and quantify the assured's liability, although the drawdowns themselves had that effect. The claim was non-US, and the ruling had the effect of postponing the assured's liability, exactly the result that it wanted.

${ }^{40}$ See generally, Mitchell, The Law of Contribution and Reimbursement OUP, 2003.
} 
which he is liable under his contract.” Thirdly, the Law Reform (Married Women and Joint Tortfeasors) Act 1935 extended the right of contribution to joint tortfeasors, with a further extension being introduced by the Civil Liability (Contribution) Act 1978 to persons being liable for the "same damage" (s 1), thereby cutting across the nature of the various wrongs and focusing on the harm suffered by the victim.

Insurance contribution and contribution under the 1978 Act differ in a number of respects: insurance contribution is calculated by reference to the insurers' respective liabilities for the claim so that each insurer must contribute rateably, whereas statutory contribution is determined by what is "just and equitable" (s 2(1)); insurance contribution is as of right, whereas statutory contribution can be ousted in the discretion of the court (s 2(2)); statutory contribution is determined at the date of the damage (s 1(3)) whereas there is authority for the proposition that insurance contribution is determined at the date of payment; ${ }^{41}$ and other provisions of the 1978 Act deal with procedural issues that do not arise as between insurers. The prevailing view before IEG was that the 1978 Act does not apply to contribution between insurers. ${ }^{42}$ As will be seen below, that is now in doubt as a result of $I E G$.

\section{Insurance contribution}

The pre-IEG authorities on the scope of insurance contribution established that double insurance, and thus the right to contribution, exist only where there are two or more policies taken out by the same person in respect of the same interest in the same subject matter against the same risks. ${ }^{43}$ The question for the majority, and obiter for the minority, in $I E G$ was whether the liabilities of Midland and Excess Insurance could be brought within those criteria, the novelty being that the liabilities arose in different policy years. The possibility of contribution across policy years had been rejected by Eady $\mathrm{J}$ in an earlier mesothelioma case, Phillips $v$ Syndicate 992 Gunner, ${ }^{44}$ although the key issue in that case - answered in the negative - was whether an insurer facing a mesothelioma claim could by an express term restricting contribution limit is liability to time on risk. Contribution across policy years was also denied by the Court of Appeal in National Employers Mutual General Insurance Association Ltd $v$ Haydon ${ }^{45}$ but the point did not arise in the direct form posed in IEG. Haydon involved consecutive claims made liability policies, the former applying to claims made or circumstances notified during its currency, and the latter excluding losses arising out of claims or circumstances notified in any earlier year. The ratio of the Court of Appeal was that this was not double insurance at all, in that the exclusion in the later policy prevented any risk from arising in respect of earlier notified claims or circumstances. It is fair to say, therefore, that the Supreme Court had to deal with the point as a matter of first impression.

The majority was prepared to extend the principle of contribution to this new context. Support was found in a series of Australian decisions to the effect that there is an extended right of contribution as long as both policies cover the same liability and there is a common assured. ${ }^{46}$ Those cases do not touch the question of contribution across years, but the majority took them as evidence that contribution was based on broad equitable considerations and to be adapted to meet "unique anomalies" ${ }^{47}$ It is submitted that the outcome is plainly correct. IEG had taken out policies with different insurers in respect of its liability arising from the risk of exposure to asbestos, so that the criteria for contribution are satisfied. The only possible objection is that each exposure gives rise to separate liability, so that it cannot be said that

\footnotetext{
${ }^{41}$ Monksfield v Vehicle and General insurance Co Ltd [1971] 1 Lloyd's Rep; Eagle Star Insurance Co v Provincial Insurance Plc [1993] UKPC 22; [1993] 3 All ER 139; Bolton Metropolitan Borough Council v Municipal Mutual Insurance \& Commercial Union Assurance [2006] EWCA Civ 50; [2006] 1 WLR 1492. The contrary view also has its supporters, rightly so because it cuts out the possibility of a defence arising between loss and payment: Legal and General Insurance Society Ltd v Drake Insurance Co Ltd [1992] 1 All ER 283; O'Kane v Jones [2005] Lloyd's Rep IR 174. Australian authority is unanimous in support of the latter view. See, eg, Limit (No.3) Ltd v ACE Insurance Ltd [2009] NSWSC 514.

${ }^{42}$ Bovis Construction Ltd v Commercial Union insurance Co Ltd [2001] Lloyd's Rep IR 321

${ }^{43}$ The summary of Gavin Kealey QC in the most recent decision, National Farmers Union Mutual Insurance Society Ltd v HSBC Insurance (UK) Ltd [2010] EWHC 773 (Comm); [2011] Lloyd's Rep IR 86, at para 15, cited with approval by the majority in $I E G$.

44 [2004] Lloyd's Rep IR 426.

${ }^{45}$ National Employers Mutual General Insurance Association Ltd v Haydon [1980] 2 Lloyd's Rep 149, reversing [1979] 2 Lloyd's Rep. 235.

46 The majority cited AMP Workers Compensation Services (NSW) Ltd v QBE Insurance Ltd [2001] NSWCA 267 and Zurich Australian Insurance Ltd v GIO General Ltd [2011] NSWCA 47 as illustrative decisions. The most recent authority is Zurich Australian Insurance Ltd v The Workers Compensation Nominal Insurer [2013] NSWSC 915, which in fact restricts the principle. See Enright and Merkin, Sutton's Law of Insurance in Australia $4^{\text {th }}$ ed 2014 , Thomson Reuters, vol 2, para 19.50.

${ }^{47} I E G$, para 59. The majority also found support from the views expressed by the present author in Insurance and the Law of Obligations, op cit, n 1, at 378.
} 
the policies cover the same loss, although the obvious response is that there is only one loss and it cannot be said that the victim can recover separately for each act of exposure.

One further tweak to insurance contribution also proved to be necessary. There are various different ways of calculating the amount of contribution between insurers, ${ }^{48}$ but it was determined in National Employers Mutual General Insurance Association Ltd v Haydon that, at least as far as liability insurance is concerned, the correct method is to apportion based upon the actual liability of each insurer for the claim rather than by reference to the maximum sum insured. That makes sense because most liability policies have high limits of indemnity, and in particular employers' liability policies are often unlimited or at worst capped at $£ 10$ million per occurrence. ${ }^{49}$ That rule plainly could not apply in IEG, because both Midland and Excess Insurance faced 100\% liability for the claim, there would be an apportionment of 50:50 despite the disparity in time on risk. Accordingly, the majority held that the measure of contribution in cross-year cases had to be time on risk rather than independent liability, a novel approach but essential to make sense of the extension of contribution to the present circumstances.

The minority ruled that English law in its present state did not support this extension to insurance contribution, and that the validity of any such extension should not be resolved in the present case. Lord Sumption cited Haydon as authority for the proposition that contribution cannot apply across policy years, although, with respect, it says no such thing. It is of interest to note that both the majority and minority were prepared to support their respective views by reference to cases which, on closer analysis, turn on quite different issues. Perhaps this is further evidence of the unique nature of the Fairchild enclave.

\section{Civil Liability (Contribution) Act 1978}

The majority saw no need to superimpose upon established equitable insurance contribution principles a statutory intervention that might lead to a different outcome. Accordingly, the majority view was that the 1978 Act had no relevance. The difficulty here is that the 1978 Act, by s 1(1), operates where any person is liable in respect of damage The weight of authority is that a claim under an insurance policy is one for unliquidated damages, arising as soon as the insured peril occurs, leading also to the consequences that damages for late payment cannot be awarded ${ }^{50}$ and that both interest $^{51}$ and the limitation period ${ }^{52}$ run from the date of the peril. On that analysis it seems to follow from the strict wording of the provision that the requirement in the 1978 Act is satisfied. The majority saw no need to discuss the correctness or otherwise of the classification of an insurance claim in its conclusion that the 1978 Act was to be disregarded, but that refusal might perhaps open the door to future arguments as to the nature of insurance claims.

By contrast, the minority saw no difficulty in the application of the 1978 Act to insurance, in that if it was the case contrary to the minority's primary view - that each insurer faced $100 \%$ liability for every act of exposure, then it followed that insurers on risk on different periods were liable for the "same damage". This reasoning necessarily leads to the conclusion that the 1978 Act applies to double insurance of the more conventional type where insurers are on risk in the same year. However, the analysis was obiter, both because it was based on a hypothesis rejected by the minority and also because the events in question occurred before the inception of the 1978 Act.

The unsatisfactory outcome is that the application or otherwise of the 1978 Act to insurance remains uncertain. It is nevertheless submitted that the majority view is to be preferred. The 1978 Act is plainly designed to facilitate contribution between persons who are liable to a victim on different grounds, and if it applies to insurance it both lays down discretionary principles inconsistent with long-established law as well as prompting the argument that the rateable contribution rule set out in s 80 of the Marine Insurance Act 1906 has been impliedly repealed.

\section{RECOUPMENT}

\section{Restitutionary principles}

The final matter addressed by the majority was whether Midland could seek to recover from IEG that part of Midland's payment representing the period during which IEG had no insurance. Equitable contribution between insurers was not available because IEG was not an insurer, and it does not appear to have been argued that Midland and IEG were liable for the "same damage" under the 1978 Act. The majority approach was to resort to general restitutionary principles.

\footnotetext{
${ }^{48}$ See O'Kane v Jones [2005] Lloyd's Rep IR 174 for discussion of them.

49 The statutory minimum, of $£ 5$ million for any one occurrence, is not found in practice.

${ }^{50}$ Because that would be damages on damages: Sprung $v$ Royal Insurance [1999] Lloyd's Rep IR 111. Law Commission proposals to reverse the Sprung rule were rejected by the Government and omitted from the Insurance Act 2015.

${ }^{51}$ Hellenic Industrial Development Bank v Atkin, The Julia [2005] Lloyd's Rep IR 365

${ }^{52}$ Callaghan v Dominion Insurance Co [1997] 2 Lloyd's Rep 541
} 
Although IEG was not an insurer, it could be regarded as a "self-insurer" in that it had chosen to bear any liability for its own account. Being akin to an insurer, it was appropriate for equity to intervene and to confer upon Midland a right to recover from IEG for the uninsured period. In so deciding, it was necessary for the majority to fashion an exception to the general principle that a defendant cannot be regarded as having been unjustly enriched by receiving a payment to which he is entitled by contract; in this case IEG was plainly entitled to be indemnified by Midland. The majority found the necessary exception in the notion that there might be unjust enrichment if wider considerations showed no policy inconsistency. ${ }^{53}$ That test was satisfied on the facts. Lord Mance treated the matter as one of contribution, although the case was argued on the related concept of recoupment, a term used by Lord Hodge and in the courts below.

However the remedy is described, the question is whether its adoption withstands scrutiny. It is submitted that it does not. Unsurprisingly, there is no authority close to the present, and it is not obvious how there can be an inequity justifying restitution if a person at risk of liability chooses not to insure for a given period but is then entitled as a matter of contract to recover for that period under a policy in force at a different time. ${ }^{54}$ The insurer, Midland, in IEG faced liability for $100 \%$ of the claim by IEG. That may not have been what was originally contemplated, but it does not of itself justify equitable relief.

Recoupment has been applied in the insurance context, but only between insurers where contribution was unavailable because the paying insurer bore no liability at all. Thus in SHC Capital Ltd v NTUC Income Insurance Cooperative $L t d^{55}$ an insurer who paid the entirety of a claim ex gratia was held to be entitled to recoupment of its payment from another insurer who did face liability but had refused indemnity: there was obviously no possibility of contribution because the claimant was not itself liable, and the analogous remedy of recoupment was appropriate. The Singapore High Court thought nothing of the defence that equity does not assist a volunteer, a principle that has no application where the volunteer acts as a matter of practical necessity. ${ }^{56}$ Again, in Limit (No 3) Ltd v ACE Insurance $L t d^{57}$ excess layer insurers who paid the full amount of the loss following wrongful denial of liability by primary layer insurers were held by the New South Wales Supreme Court to recoupment of their payment: once again, contribution was inapplicable because the excess layer insurers were not liable for the primary layer loss.

Recoupment has never been applied against an assured, whether or not underinsured. Indeed, it is submitted that it could not. Within a single policy year, the assured is either fully insured or he is underinsured. If the assured is fully insured, he recovers from the insurers the full sum payable under the policy for the loss. If the assured is underinsured, then he bears the shortfall himself, but it is only in the marine context that underinsurance leads to any form of sharing between the insurer and the assured. That is the result of the principle of average set out in s 81 of the Marine Insurance Act 1906 under which the assured is deemed to be his own insurer for any uninsured sum. Even then, average bites only in the case of a partial loss. Thus, if a vessel is worth $£ 1,000,000$ and is insured for $£ 800,000$, in the event of a total loss the assured recovers $£ 800,000$, an outcome replicated if the insured subject matter is a building or a watch. However, if the assured suffers a partial loss of a vessel worth $£ 1,000,000$ and insured for $£ 800,000$, and the repairs cost $£ 500,000$, the insurer's liability is restricted to $8 / 10$ ths of that figure by reason of average because the insurer is only on risk for 8/10ths of any loss, whereas the owner of terrestrial property would in that situation recover the full loss of $£ 500,000 .^{58}$ This is not recoupment, it is simply the case that the assured does not have full cover for his loss even though the insurer is still paying to the limits of its liability. If that principle applies to underinsurance in a single policy year, it is not easy to see why there should be a different outcome where there is underinsurance in a different year.

If there is to be recoupment, then, stripping away the legal niceties, the proposition becomes either that an insurer can reduce its own contractual liability by means of apportionment where the assured has agreed to bear a part of the loss, or that an insurer can sue its own assured. Neither proposition has any support in the authorities.

\section{Apportionment in insurance law}

It is now settled that apportionment is simply not a part of insurance law, subject only to the modification of the marine concept of average where there is underinsurance. Where full cover is in place, the insurer must pay the policy moneys

\footnotetext{
${ }^{53}$ In reliance on general propositions put forward in Burrows, The Law of Restitution, $3^{\text {rd }}$ ed 2011, 88-91. See also Mitchell, Mitchell and Watterson, Goff and Jones, The Law of Unjust Enrichment $8^{\text {th }}$ ed, 2011, Part 3.

${ }^{54}$ The minority reasoning is to similar effect: see para 187. See also the almost summary view of the lower courts in rejecting the suggestion: [2012] EWHC 69 (Comm) (Burton J, para 42); [2013] EWCA Civ 39 (Toulson LJ, para 37, with whom Maurice Kay and Aikens LJJ agreed).

54 [1993] AC 713.

55 [2010] SGHC 224.

${ }^{56}$ Following the lead of the Court of Appeal in Drake Insurance Plc v Provident Insurance Plc [2003] EWCA Civ 1834; [2004] QB 601.

57 [2009] NSWSC 514.

58 Assuming no excess and no average clause.
} 
without deduction, as long as all of the loss is within the terms of the cover. That point emerges from the numerous authorities on mitigation of loss or, in marine terminology, suing and labouring. A marine assured who takes steps to prevent or mitigate loss is entitled to be indemnified for any expenses properly incurred, ${ }^{59}$ and if that expenditure confers an incidental benefit on the assured the insurer is not entitled to seek a deduction in respect of it unless the expenditure on insured and uninsured matters is clearly severable. Thus, if the assured incurs expenditure in securing the release of a seized (insured) vessel, the fact that the expenditure incidentally secures the release of the (uninsured) crew does not entitle the insurers to deduct anything from the sum payable. ${ }^{60}$ Outside marine insurance there is no right to recover the costs of mitigation unless there is a clause to that effect. Such a case was Ace European Group v Standard Life Assurance Ltd ${ }^{61}$ where the assured under a professional indemnity policy was held to be entitled to recover the full amount of its mitigation costs in restoring an investment fund to its previous value even though the assured had mixed motives in preventing claims by investors (insured) and preserving its own market reputation (uninsured). Tomlinson LJ here emphasised that apportionment, insofar as it exists in English insurance law, is confined to the marine principle of average. The same principle was, in New Zealand Forest Products Ltd $v$ New Zealand Insurance Co Ltd, ${ }^{62}$ extended by the Privy Council to insured defence costs incurred by an assured under a liability policy: the fact that the expenditure benefits uninsured persons, or relates to uninsured claims, does not permit apportionment as long as the amount has not been increased by reason of the inclusion of uninsured matters. Indeed, in IEG itself IEG was unanimously held to be able to recover from Midland the full $£ 13,151.60$ that it had incurred by way of defence costs in respect of Mr Carré's claim. Although the Midland policy related only to $22.08 \%$ of the period of exposure, it had not been shown that the costs had been increased by the fact that IEG's liability extended across 27 years. The majority in $I E G$ were thus forced to explain why a right of recoupment existed for the policy moneys themselves but not for defence costs, and did so by noting that the "weak" causation test applied to the policy moneys but the ordinary "but for" causation test applied to defence costs. That somewhat begs the question of why a weak causation test should lead to a right of recoupment.

\section{Can an insurer sue its own assured?}

The suggestion that an insurer can exercise a right in restitution against an assured to recoup a payment made under the policy is on its face a surprising one. The insurer is either liable or not. There are nevertheless two exceptions permitting a claim. The first arises where the insurer has paid and then discovered a vitiating factor affecting the claim, including a defence under the policy unknown at the time, ${ }^{63}$ payment under some form of mistake ${ }^{64}$ or a subsequent discovery of fraud in the claim. ${ }^{65}$ In these cases there was never truly a valid claim for some or all of the loss in the first place, and so principle is not offended. Secondly, by contrast, there may be cases where the insurer is required to make payment but has a right of recourse against the assured. This may arise by operation of law, the best - and perhaps the only - example being s 151(8) of the Road Traffic Act 1988, under which an insurer who is required to meet a claim by the victim of an uninsured driver under s 151(2) may seek recoupment from any person (including the policyholder) who has caused or permitted the uninsured driving of the vehicle. Alternatively, the insurer may be liable to make payment under the policy to a third party in respect of a claim against the assured but has reserved a right of recoupment in specified circumstances. There may be contractual provisions to this effect, ${ }^{66}$ and there is a statutory illustration in s 148 of the Road Traffic Act 1988, which prevents a motor insurer from relying upon specified policy restrictions where a claim is brought by a third party but which allows the insurer to include recoupment provisions in the policy if the policy restriction would but for the statute have been enforceable.

Such exceptional possibilities aside, there is no authority holding that an insurer who is liable to make payment under the policy to an assured, has a right of recourse against that assured. The issue has been considered in the context

\footnotetext{
${ }^{59}$ Marine Insurance Act 1906, s 78(1). The right to payment is stated by the section to arise only where there is a suing and labouring clause in the policy: as that is invariably the case, there is no need here to consider the position where the policy is silent.

${ }^{60}$ Royal Boskalis Westminster v Mountain [1997] 2 All ER 929; Atlasnavios v Navigators Insurance Company Ltd, The B Atlantic [2014] EWHC 4133 (Comm).

${ }^{61}$ [2012] EWCA Civ 1713.

62 [1997] UKPC 37; [1997] 1 WLR 1237.

${ }^{63}$ The scope of the mistake defence in these circumstances is limited as a result of Great Peace Shipping Ltd $v$ Tsavliris Salvage (International) Ltd, The Great Peace [2002] EWCA Civ 1407; [2003] QB 679, disapproving the invoking of a wider equitable jurisdiction in these precise circumstances in Magee v Pennine Insurance Co Ltd [1969] 2 QB 507.

${ }^{64}$ Norwich Union Fire Insurance Society Ltd v William Price Ltd [1934] AC 555.

${ }^{65}$ Hayward $v$ Zurich Insurance Co plc [2015] EWCA Civ 327, where a distinction was drawn between an insurer who settled unaware of fraud (entitled to avoid), and an insurer who settled aware of fraud but who later discovered further evidence of fraud (not entitled to avoid) - Hayward was of the latter type.

${ }^{66}$ See the discussion of policy excesses, below.
} 
of subrogation rights against an assured. ${ }^{67}$ In Simpson $v$ Thomson ${ }^{68}$ the insurers of a shipowner paid for collision damage and sought to recover their payment from the shipowner by way of subrogation, as the damage had been caused by another of the shipowner's vessels. The action was doomed to fail, not the least because a subrogation claim has to be brought in the assured's own name so that the assured would have been suing himself. Lord Mance was able with some ease to dispose of Simpson $v$ Thomson as a barrier to the recoupment principle, ${ }^{69}$ but further analysis might have presented greater problems. The subrogation point is of significance where the policy covers the separate interests of both A and B under a "composite" cover $^{70}$, and the insurer, having indemnified A, seeks to recover its payment from $\mathrm{B}$ on the ground that B's conduct has caused the loss. After some vacillation in the cases, it is now clear that the arrangement between A and B is all but inevitably to be construed as one under which A agrees to look to the insurer alone, so that B has subrogation immunity on the basis that there is no claim against him. That is so even where B is in breach of contract in causing the loss ${ }^{71}$ or where B has agreed to provide a contractual indemnity to A. ${ }^{72}$ In short, if B is a policyholder, he is entitled to subrogation immunity even though he may not have been insured for the precise loss that occurred. ${ }^{73}$ Indeed, in exceptional cases the courts may, as an alternative means to the same outcome, imply a term into the policy precluding subrogation against a composite assured. ${ }^{74}$

What these cases show is that an insurer does not have any general right to seek recovery of policy moneys properly paid under the policy from a person insured under that policy, even if that person's negligence has caused the insured loss. In $I E G$, itself, the employer's wrongdoing consisted of no more than choosing not to take out insurance for a period during which it faced liability to employees, an omission which did not affect the liability of Midland to make good the entire loss under Midland's own policies.

\section{Self-insurance}

It has been noted that the recoupment remedy was in part justified by the majority because IEG was to be regarded as a "self-insurer". If the employer is so labelled, the argument that restitution is possible is given credence. However, as Lord Sumption's powerful rebuttal points out, self-insurance is not a concept recognised by law, it is merely a way of saying that there is no insurance. ${ }^{75}$ Outside the marine context of average, self-insurance arises in two ways: the assured bears an excess, which relieves the insurer from liability for the amount of that excess; and the assured is underinsured. To describe the assured as "self-insured" for those sums implies that the assured is to be treated as an insurer. But that is not the case. If it were, every non-marine policy would be subject to average. The point is made by Lord Napier and Ettrick $v$ Hunter ${ }^{76}$ where the House of Lords discussed the allocation of a subrogation recovery as between an assured who was both underinsured and who bore a policy excess. Their Lordships treated the situation as if it were insurance in three layers: a primary layer, consisting of the excess; a second layer consisting of the insured sum; and a third layer consisting of the uninsured loss. It was held that the subrogation recovery was to be allocated on a "recover down" basis, so that the third layer was to be paid off first. If there was a shortfall, the excess was the most likely victim. But that outcome was not predicated on the assured being a self-insured and thus akin to an insurer. Had that been the case, the subrogation proceeds would not have been paid on a recover down basis, but rather allocated between the assured and the insurer proportional to their participation in the risk, as in marine insurance. ${ }^{77}$

The excess borne by the assured serves four functions. First, because the majority of losses are small, an excess cuts out many claims. That is directly linked to the second function, which is that an excess dramatically reduces the premium, in that cutting out small claims is a major saving in time and cost for any insurer. An assured whose motor

\footnotetext{
${ }^{67}$ Subrogation is the right of an insurer, or indeed any contractual indemnifier, to recover its payment from a third party responsible for the loss suffered by the indemnified party in respect of which the indemnity was provided. 68 (1877) 3 App Cas 279.

${ }^{69}$ But see James, "The Fallacies of Simpson v Thomson" 2 MLR 149 (1938).

${ }^{70}$ If the interests of A and B are indivisible (as with spouses) the policy is "joint" and their rights stand and fall together, so the point does not there arise.

${ }^{71}$ Gard Marine \& Energy Ltd v China National Chartering Co Ltd [2015] EWCA Civ 16.

${ }^{72}$ Rathbone Brothers Plc v Novae Corporate Underwriting Ltd [2014] EWCA Civ 1464.

${ }^{73}$ As in Rathbone, where the events giving rise to the claim against A under a liability policy predated B's involvement with A.

${ }^{74}$ The majority view in Rathbone. It may be noted that, before Rathbone, the implied policy term had been thought to be the route to B's immunity. The authorities are discussed at length in that decision.

75 The same comment was made by Burton J at first instance, [2012] EWHC 69 (Comm), para 42. See also Associated Forest Holdings Pty Ltd v Gordian Runoff Ltd [2015] TASFC 6, where the Full Court of Tasmania treated an employer exempt from workers compensation legislation as a "self-insurer" so that its outward protection was reinsurance rather than insurance: the policy was indeed in the form of an excess of loss reinsurance treaty rather than one of liability insurance

76 [1993] AC 713.

77 The Commonwealth [1907] P 216.
} 
policy does not have an excess will typically pay a disproportionately higher premium than an assured bearing a high excess. Thirdly, although this depends upon one's view of the importance of deterrence by the civil law, an excess imposes some responsibility upon the assured so that there is incentive to avoid losses. Fourthly, an excess can serve as a risk-rating mechanism: reverting to the world of motor insurance, the excess imposed upon an inexperienced driver is generally much higher than the excess borne by an old hand.

But none of this requires classification of the assured as a self-insurer. Excess clauses vary in their wording, but it is common to find phraseology to the effect that the insurer will not pay the first $£ X$ of any loss or claim. ${ }^{78}$ That does not mean that the assured has to remain its own insurer. Commercial policies may have substantial excesses, and the assured may well choose to insure the excess under a separate policy, albeit at a higher premium, sometimes with a different insurer or sometimes with the same insurer under separate arrangements. ${ }^{79}$ There is no objection to an assured insuring the excess elsewhere, at least in the absence of a policy restriction to that effect, ${ }^{80}$ and the fact that the assured has insured elsewhere is not a material fact to be disclosed to insurers ${ }^{81}$ under the pre-contractual duty of fair presentation. ${ }^{82}$ Indeed, compulsory employers' liability policies issued in accordance with the 1969 Act must not have excesses, to ensure that any victim is fully compensated, and the best that an insurer can do is to insert into the policy a clause which, in the event of a third party claim, requires the assured to repay to the insurers a sum representing what would have been the excess. ${ }^{83}$

The submission here is that the correct classification of an excess clause is a first-loss sum for which the insurer does not accept liability. To jump from that negative position to the positive statement that the assured is thereby his own insurer for that amount is a false step. That is even more so when the assured actually does have full insurance cover by the terms of the policy.

\section{Is recoupment significant?}

It is important to stress that the recoupment argument arose in IEG because IEG was not insured for the bulk of the period of exposure, and was not by the law of Guernsey at the time required to be insured. In the UK, the recoupment analysis is the most controversial but also the least important feature of the ruling, at least in the employment context. That is so for two reasons. First, since 1972 it has been compulsory for employers to insure against liability to employees under the Employers' Liability (Compulsory Insurance) Act 1969, and the vast majority of employers would have had insurance in place. Recoupment necessarily arises only where there is no insurance. The major exception relates to local authorities, which are exempt from the 1969 Act and many of them chose not to seek external insurance. Secondly, in many cases the employer against which recoupment is sought will either have been removed from the register of companies or, if still extant, insolvent, so that the recoupment claim is simply notional. That type of company is typically the most likely not to have carried compulsory liability insurance. ${ }^{84}$ It is also to be remembered that a director of a company who has allowed the company to operate without insurance does not face liability for breach of statutory duty, ${ }^{85}$ a principle recently confirmed by a majority of the Inner House of the Court of Session, ${ }^{86}$ and so there is no possibility of a subrogation claim to make good the loss suffered by the paying insurer for loss of the recoupment claim.

Thus, although the principle developed by the majority may be fraught with difficulty in conceptual terms, ${ }^{87}$ it is unlikely to be of practical significance in the employment context. It may be relevant where exposure is by persons

\footnotetext{
${ }^{78}$ There may also be an aggregate excess, based on losses or claims arising out of any one event or originating cause,

79 A form of cover known as "deductible buy-back".

${ }^{80}$ Halvanon Insurance $v$ Central Reinsurance [1984] 2 Lloyd's Rep 420.

${ }^{81}$ SA d'Intermediaries Luxembourgeios v Farex Gie [1995] LRLR 116

${ }^{82}$ As reclassified by the Insurance Act 2015 from the old duty of utmost good faith.

${ }^{83}$ Policies issued before the 1969 Act came into force were generally not subject to any excess. Where there is an excess, insurance can be obtained against liability to repay the excess, a device adopted by Turner $\&$ Newall, a leading supplier of asbestos products, whose policy set out a deductible of $£ 690$ million. For the most recent stage in the lengthy litigation, see Federal Mogul Asbestos Personal Injury Trust v Federal-Mogul Ltd [2014] EWHC 2002 (Comm).

${ }^{84}$ The operation of the 1969 Act was reviewed by the Department of Work and Pensions in 2002, http://www.detini.gov.uk/dw2583 employers_review.pdf. It appears from this report that compliance "remains high": $\mathrm{p} 13$.

${ }^{85}$ Richardson v Pitt-Stanley [1995] 1 All ER 460.

${ }^{86}$ Campbell v Peter Gordon Joiners Ltd [2015] CSIH 11.

${ }^{87}$ There is lengthy discussion by the majority as to how a right of recoupment might operate where the employer is insolvent and the claim is brought directly against the insurer by the victim under the Third Parties (Rights against Insurers) Act 1930 or 2010. Lord Mance concluded that the insurer would not be entitled to set-off from the sums payable under the policy the amount of any recoupment claim, either because such a claim did not arise under the
} 
who are not required to be insured, eg, local authorities, if they do not actually carry insurance. However that is only the case in respect of employers' liability: as regards public liability the Bolton decision, if good law, takes such defendants outside the Fairchild enclave. It may be questioned why it was thought necessary to extend the law in such a dramatic fashion when the facts giving rise to that extension were all but unique. The real danger from the majority analysis is that it may be cited in the future as authority for the proposition that an insurer has some sort of restitutionary claim against the assured in circumstances where the insurer has paid the full contracted amount under the policy. Statute, fraud and other vitiating factors aside, it is submitted that the possibility does not form any part of English law.

\section{APPLICATION OF THE PRINCIPLES}

\section{Assumptions}

The insurance principles, albeit controversial, are now settled by Trigger and IEG. But they still have to be applied. In such application the reinsurance market is crucial. In the following examples, a number of assumptions are made: the events occurred in Great Britain; there is no relevant cap on the liability of any insurer and no exhaustion of annual coverage by other claims; the intensity of exposure is identical throughout the relevant period so that the only variable is time on risk; there has been no exposure to asbestos other than by the employers in question so that atmospheric and other possible causes of mesothelioma can be discounted; ${ }^{88}$ and that any reinsurance relates to the year in which the insurer itself faces liability. Introducing those variables would render already complex scenarios all but incomprehensible. ${ }^{89}$

\section{Scenario 1: single employer and single insurer}

Employer A has employed employee $\mathrm{E}$ for a continuous period of 10 years during which $\mathrm{A}$ has exposed $\mathrm{E}$ to asbestos. Throughout that period A has been insured by insurer I. The Compensation Act 2006 has no part to play here, as there is only one liable employer, A, who may be sued for $100 \%$ of I's loss. There is no other tortfeasor in place, so A's actions must have been the proximate cause of E's injury, and accordingly E can recover from A independently of Fairchild. It is also the case that A can recover from I, applying the Trigger principle that exposure is the basis for A's coverage under the policy.

E does not have to mount his claim in any specific year. Fairchild nevertheless makes it clear that if E wishes to identify a year, he can chose any one of them, although of course there is no reason why E would have any need or motive to do so. Equally, given that under Trigger every exposure by A attracts cover under the policy, A can choose any year of coverage for his claim, but - on the assumption of adequate and non-exhausted cover - once again there is no reason why A should need to do so. The outcome is that I has to pay a claim by A, but there is no way of knowing to which year it belongs.

This is the point at which I's reinsurance becomes relevant. If I has been reinsured by one reinsurer, RR1, for the entire period, then on the majority view in IEG I has a straightforward claim against RR1, often ${ }^{90}$ without the need to allocate between RRI's years of coverage. ${ }^{91}$ However, that scenario is most unlikely. I is almost certain to have been reinsured in each year by a number of reinsurers subscribing to the reinsurance for their respective proportions, and the identities of those reinsurers as well as the proportions of their coverage will all but inevitably have varied from year to year. ${ }^{92}$ The question for I is, therefore, how the reinsurance claims are to be allocated. The Supreme Court made it clear

policy itself or (a point on which there is a conflict of authority) because set-off was precluded by the legislation. The minority pointed to this analysis as further evidence of the artificiality in the majority approach.

${ }^{88}$ See Sienkiewicz v Greif (UK) Ltd [2011] UKSC 10; [2011] 2 AC 229; Steel and Ibbetson, "More Grief on Uncertain Causation in Tort" (2011) 70 CLJ 451. If there was another period of exposure by a non-employer with a public liability policy, responding under Bolton to the year of injury, the fun would really start.

${ }^{89}$ Interestingly, Lord Hodge was of the view (para 110) that the principles laid down by the majority in IEG were consistent with market practice and would not cause major practical difficulties. That statement is not borne out by the intervention of the Association of British Insurers in the proceedings, arguing for the "time on risk" principle ultimately accepted by the minority. The statement is certainlye aspirational rather than factual once attention is focused on the reinsurance implications.

${ }^{90}$ But not always. There may be annual aggregate limits or deductibles for each year of the reinsurance, so full recovery is possible only if losses are spread across policy years.

${ }^{91}$ RR1 may face problems with its own outward reinsurance - retrocession - where there are different retrocessionaires on risk from year to year during RR1's period of coverage of I, but that is the same problem, albeit once removed, as different reinsurers in the years of I's coverage, discussed in the text.

${ }^{92}$ In practice much of this type of business was insured by Lloyd's Syndicates. 
in both Teal and IEG that allowing an assured (or a reinsured) to pick and choose the order of claims is contrary to the concept of uncertainty which underpins insurance, but it is difficult to see how offending the principle can be avoided in this scenario on the majority view. I has a claim in every year, and can press his claim however it wishes. There may be reasons for I choosing a particular year, eg, restrictions or exhaustion of coverage, the insolvency or run-off of one or more reinsurers or the absence of any continuing business relationship with one or more of them, but it is not clear what principle exists to prevent I from selecting coverage in such years as maximises I's recovery. It might be argued that I has some form of duty of good faith to insurers in making its selection, but s 17 of the Marine Insurance Act 1906 - even in the form amended by the Insurance Act 2015 to remove avoidance as the sole remedy for breach - is scant authority for such a proposition. That said, in Australia, where the duty of utmost good faith owed by the parties is contractual, under s 13 of the Insurance Contracts Act 1984 (Cth), ${ }^{93}$ there is no decision which comes close to holding that any such duty exists. Indeed, the indications in the cases are to the contrary. ${ }^{94}$ There is important US authority which suggests that there is a general duty on a reinsurer to "follow the fortunes" of its reinsured, by indemnifying the reinsured whenever a payment is made by the reinsured to its policyholders, unless the reinsured has acted in bad faith. For that purpose a reinsured who merely seeks to maximise recovery is not necessarily acting in bad faith bad faith. However, the cases are not consistent ${ }^{95}$ and English law does not in any event recognise an implied duty upon a reinsurer to f'ollow the fortunes". The matter is in practice dealt with in English law contracts by an express obligation on the reinsurer to "follow the settlements" of the reinsured. The English formulation means that the reinsurer must pay as long as the settlement reached by the reinsured was entered into bona fide and in a businesslike fashion. ${ }^{96}$

It can only be concluded that, on the present state of the authorities I can allocate its reinsurance coverage where it thinks fit. The allocation problem is the same in this scenario on either the majority or minority views in IEG, because both sets of reasoning proceed on the basis that I is liable for exposure in the period of its own insurance although there is no discussion as to how that exposure is to be allocated as between reinsurers. Nevertheless, it is possible to extrapolate the outcome. On the majority view, if I targets RR1, then RR1 can - on the strength of $I E G$ - seek contribution from the other reinsurers on risk and against whom claims could have been made by I. Equally, if I had no reinsurance for any part of the period of its insurance of A (unlikely in practice) then RR1 would have an IEG recoupment action against I. By contrast, if the minority view is correct then, if the losses are assumed to be regular, they would fall to be allocated proportionately to each year of reinsurance cover and recoverable in that way, in accordance with MMI $v$ Sea Insurance.

\section{Scenario 2: single employer and consecutive insurers}

Employer A has employed employee $\mathrm{E}$ for a continuous period of 10 years during which $\mathrm{A}$ has exposed $\mathrm{E}$ to asbestos. In years 1-3, A has been insured by Insurer 1; in years 4-7, A has been insured by Insurer 2; and in years 8-10 - in breach of its duties under the Employers' Liability (Compulsory Insurance) Act 1969 - A has not had insurance in place. This is close to the scenario faced by the Supreme Court in $I E G$, the only difference being that the Compensation Act 2006 potentially comes into play. However, the 2006 Act is not needed. As in Scenario 1, A is the only exposing employer and thus faces liability for $100 \%$ of the loss even on the "but for" test of causation. But, under Fairchild, A faces liability to E in every year of exposure.

As far as the insurers are concerned, the majority ruling in IEG now comes into play. Under Trigger both I1 and I2 face liability, given that exposure has occurred in their years of coverage. Under IEG employer A can decide how to allocate its claims. Once again the rule against allocation in Teal is offended, but it was recognised by the majority in IEG that A can in the face of Teal allocate as it wishes, subject to contribution and recoupment. So, on the face of things, if A claims against I1, I1 has to pay the full amount of the loss but can recover 4/10ths of its payment from I2 by way of contribution and 2/10ths from A by way of recoupment. In that way both I1 and I2 have claims against their reinsurers representing their apportioned liability, assuming full recovery under the contribution and recoupment processes. $^{97}$

${ }^{93}$ By analogy, because the 1984 Act does not apply to reinsurance.

${ }^{94}$ Camellia Properties Pty Ltd v Wesfarmers General Insurance Ltd [2013] NSWSC 1975, where the assured was held not to have been in breach of its contractual duty of utmost good faith, following a fire at his premises, by applying to the local authority for development consent with the effect that the rebuilding costs to be incurred by the insurers were raised.

${ }^{95}$ Tavelers Casualty and Surety Co v Insurance Co of North America 609 F 3d 143 (2010); United States Fidelity and Guaranty Co v American Reinsurance Co 985 NE 2d 876 (2013).

${ }^{96}$ See Tokio Marine Europe Insurance Ltd v Novae Corporate Underwriting Ltd [2014] EWHC 2105 (Comm).

${ }^{97}$ But a further problem arises, based on the facts of IEG, if IEG had been insolvent. Zurich would then have been unable to recoup anything from IEG, leaving itself with its own 6 years, two year contribution from Excess and a worthless 19 year recoupment claim from IEG. Would that loss have been borne by Zurich alone, or would Excess have been required to contribute its proportion of the failed recoupment? In other words, could Zurich have sought contribution from Excess for the 19 years of non-insurance on a 6:2 ratio? It seems curious if that was not the case: the 
But where the claim is brought by A only against I1, problems will arise if for any reason I 2 would not have faced liability to A and so cannot be called upon to contribute, or if either I 2 or A is insolvent and has no ability to meet a recoupment claim. In those cases, the contribution and recoupment claims will fail and I1 will be left with a degree of liability that, but for immunity or insolvency, it could have passed on. The majority in IEG transferred to the insurer called upon to make payment the risk of the insolvency of other insurers and the self-insurer. What, in that situation, are I1's right against its reinsurers? There are two possible responses.

The first is that the majority view in $I E G$ carries through to the reinsurance level. The second rests upon the insistence of the House of Lords in Wasa $v$ Lexington that a reinsurer cannot be liable beyond the agreed duration of its cover, so that whatever the insurance says about duration the reinsurers are not bound by anything other than their own wording.

It is submitted that the first must be right. It would be odd if that was not the case, given that Trigger and IEG carried Fairchild through to the insurance, and there is no logic in stopping short at reinsurance. Further, the key element in Wasa is missing, namely, the uncertainty as to the applicable law. In the situation under consideration, the law applicable to the employers' liability policy is known to the reinsurers at the outset to be English law. Admittedly its content has changed as a result of Fairchild, but it was made clear in Wasa that an underwriter has to bear the risk of a change in the law however bizarre that change might be. ${ }^{98}$

At this point the picture becomes less clear. I1's period of cover in years 1-3 will almost certainly have been characterised by annual changes to the identities in some or all of the reinsurers. The logic of IEG is that 1I can allocate its loss (including loss arising from its inability to claim contribution or recoupment from I2 and A) to any year of reinsurance coverage, because it faces $100 \%$ liability in each of those years. It is then to be left to the reinsurers to sort out contribution issues between themselves in accordance with IEG. But how are they to do it? Assume that, in respect of the reinsurance of I1, RR1 is on risk in years 1-2, and RR2 is on risk in year 3. I1 then claims against RR1. Under $I E G$, RR1 is liable for: (a) its own two years of cover, years 1-2; (b) RR2's year of cover in year 3; (c) I2's years of cover, years 4-7; and (d) A's period of self-insurance, years 8-10. Plainly RR1 can recover period (b) from RR2. But what of the periods (c) and (d)? If RR1 does have a contribution claim against RR2, is it for half of those periods or is it for one-third to reflect the respective times on risk for RR1 and RR2? IEG provides no obvious answer to that problem, and indeed there does not seem to be one.

\section{Scenario 3: multiple employers and consecutive insurers}

This is the most complex of the possibilities. The scenario is that $\mathrm{E}$ has been exposed to asbestos by A1 in years 1-5 and by A2 in years 6-10. A1 was insured by I1 in years 1-3 and y I2 in years 4-5. A2 was insured by I3 in years 6-7, by I4 in years 8-9 and A2 did not have insurance in year 10. E makes a claim against A1. We know from Fairchild that R1 is liable in every year that A1 employed E, and we know that A2 is also liable on the same basis. However, we also know that A1 can allocate its claim in any one of years 1-5, and that A2 could have done the same had it been the defendant. If, therefore, A1 seeks indemnity from I1, and I1 pays the entire loss, what are the rights of I1 against I2, I3, I4 and A2?

As against I2, the position is straightforward. I2 has to contribute to the extent of its time on risk, so that I1 would get back a proportion of the loss representing I2's two years of coverage. I1 does not have a personal contribution claim against $\mathrm{I} 3$ or I4, because different assureds are involved and contribution requires a common assured. There is an intriguing possibility that I1 might have a recoupment claim against A2 in respect of year 10 when there was no coverage in place, but that would require a further extension of the law. It would seem, therefore, that if I1 is to recover from I3 and I4, and possibly A2, for their time on risk, it would have to be done by means of a subrogated action under which I1 would use R1's name to seek contribution from A2, thereby triggering the liability of I3 and I4 to indemnify A2. The question then becomes, are A1 and A2 liable for the "same damage" under the Civil Liability (Contribution) Act 1978? Lord Sumption's analysis of the 1978 Act would appear to resolve this matter. Lord Sumption accepted, on the hypothesis that the majority was correct in treating each exposure as a tort, that the obligation of each of the insurers to indemnify the assured was in respect of the "same damage". That must surely apply equally to the individual employers facing liability to the victim. It is all but inconceivable that the majority would have accepted any different outcome, given the need for matching cover within the Fairchild enclave.

risk of unrecoupable sums would have fallen on the insurer chosen as the relevant defendant rather than split between the two insurers in proportion. Surely it is inconsistent with the reasoning in $I E G$ that the loss should fall, fortuitously, on the insurer against whom proceedings are brought.

${ }^{98}$ In Wasa the reinsurers did not seek to pray in aid the argument that the US judgment should be disregarded on the grounds of "manifest absurdity", a defence potentially open to them: see Commercial Union v NRG. However, a good deal of their oral submissions to the House of Lords were designed to cast doubt on the credibility of the US decision, and did so to some effect. 


\section{CONCLUSION}

Fairchild has proved to be a classic example of the ripple effect or, perhaps more unkindly, chaos theory. The House of Lords in Fairchild sought to find a means to compensate individuals contracting mesothelioma following exposure to asbestos, by finding a self-contained and exclusive exception to the "but for" causation test. As noted earlier, the exception was greeted with horror by purists and with enthusiasm by pragmatists. It was always apparent that the exception would give rise to further questions - despite denials in Fairchild itself - as to whether it could be extended to other situations where science could not provide the necessary link between injury and harm. Barker put an immediate brake upon the use of Fairchild's potential to impose disproportionate liability, and despite the intervention of the Compensation Act 2006 causation in tort law has, other than in the pages of academic journals and texts, survived relatively unscathed, at least for the present. There is no difference in principle between mesothelioma and other diseases with indeterminate triggers, and extension may prove to be irresistible unless Fairchild is really can be treated as a one-off and short-term exception to a specific problem of diminishing significance.

The same cannot be said for the law of insurance, where the problem has not been any conceptual extension of Fairchild but rather how Fairchild carries through to the very insurance and reinsurance cover necessary to give effect to the outcome in that case. Any explanation of Fairchild divorced from its insurance implications is both incomplete and misleading, and perhaps has wider lessons for the teaching of tort law generally. Trigger initially dealt with the possibility of coverage, and IEG has now considered the further matter of allocation to policy years. The Fairchild enclave in its gradual expansion has required a variety of modifications to legal principle. Trigger itself created the situation - deliberately left unresolved by the judgments in that case - that the words "injury sustained" and "disease contracted" bear different meanings as between public liability and employers' liability policies, a position which might be thought to be unsustainable. The majority in $I E G$ found it necessary, in order to match insurance coverage to Fairchild, to expand the concept of insurance contribution, to develop a dangerous principle which opens the door to claims by insurers against their own policyholders, to analyse the operation of the Civil Liability (Contribution) Act 1978 and to review the operation of the third party cut-through in the Third Parties (Rights against Insurers) Acts 1930 and 2010. It is difficult to choose between sympathy for the majority view that this has to be seen through to the bitter end and the minority view that, had later events been foreseen, the House of Lords in Fairchild would have contented itself with the wringing of hands and demands for the mesothelioma problem to be resolved by Parliament, ${ }^{99}$ perhaps through a state-funded scheme that would have left insurance principles unaffected.

But this is not over. The Fairchild enclave ever widens. Teams of lawyers acting for the reinsurance market have had a "watching brief" over the Trigger and IEG litigation, and the next battle - at that level - now looms. It would be curious in the extreme if the enclave did not encompass reinsurance, but that can only happen if further exceptions to established principle within the enclave are to be developed.

${ }^{99}$ See Lords Neuberger and Reed, at para 211. 